\title{
Measuring Students' Use of Zoom Application in Language Course Based on the Technology Acceptance Model (TAM)
}

\author{
Hind Abdulaziz Alfadda ${ }^{1} \cdot$ Hassan Saleh Mahdi ${ }^{2}$ (D)
}

Accepted: 20 December 2020 / Published online: 5 January 2021

(c) The Author(s), under exclusive licence to Springer Science+Business Media, LLC part of Springer Nature 2021

\begin{abstract}
The study uses technology acceptance model (TAM) to gain insights into user reactions to the technology adopted for language learning. The study aims to analyze the correlation between the variables of TAM on using Zoom application in language learning, in addition to examining how gender and experience influence the use of technology. The participants of this study comprise of 75 undergraduate English-as-Foreign-Language learners who have studied for their courses online during the COVID-19 pandemic. The results of the study reveal a strong positive correlation between the actual use of Zoom and the students' attitudes and behavioral intention. In addition, there is a positive correlation between computer self-efficacy and other variables (i.e. PU, actual use, PEU, attitude and behavioral intention). Further, while the results reveal that there is no correlation between the gender and any variables of the model, it has been found that experience is positively correlated with the variables of TAM.
\end{abstract}

Keywords Technology acceptance model $\cdot$ Language learning $\cdot$ Attitudes $\cdot$ Zoom . Gender · Experience

\section{Introduction}

Utilized by a substantial number of students, online learning is described as "access to learning experience via the use of some technology" (Moore et al. 2011, p. 130). While almost one-third of all post-secondary students utilize this form of learning in some manner, the decision to participate in online learning is often made by the students themselves (Al Fadda 2020). However, in recent months, unprecedented global events have made online learning compulsory rather than optional.

Hind Abdulaziz Alfadda

halfadda@ksu.edu.sa

$\bowtie$ Hassan Saleh Mahdi

almatari7@gmail.com; hsmohammed@ub.edu.sa

1 Department of Curriculum and Instruction, King Saud University, P.O. Box: 1914, Riyadh, Saudi Arabia

2 Department of English, College of Science and Arts, University of Bisha, Balqarn, Bisha 61922, Saudi Arabia 
The COVID pandemic began as an outbreak of a cluster of pneumonia cases reported by health authorities in Wuhan, China in December 2019. By March 11, 2020, the spread of the virus to other countries led the World Health Organization to declare COVID-19 a pandemic (World Health Organization 2020). By March 30, 87\% of the world's schools had closed, propelling 1.5 billion students and educators into unchartered territory (Winthrop 2020). The novel coronavirus pandemic (COVID-19) impacted society in myriad ways, perhaps the most significant of which was in the form of a major change to the educational system of nations. With the suspension of face-to-face learning on campuses, many university teachers and students began to use Zoom as an educational tool for delivering and receiving information and continuing educational communication and discussion.

This study measured students' experience of using the Zoom web conference system as a tool for mediating the transition to at-home learning. This included online learning during the epidemic in the light of the technology acceptance model, which served as the theoretical basis for this research. While earlier studies had applied the TAM model on different applications and learning environments such as Wiki (Liu 2010) and BlackBoard (Landry et al. 2006), a survey of existing literature showed that the TAM framework has not been used to investigate user attitudes to the Zoom application. Therefore, this study aims at exploring the students' perceptions of using Zoom Technology in language learning in terms of Perceived Usefulness (PU), activities, Perceived Ease of Use (PEU), attitude and behavioral intention.

\section{Review of Literature}

\section{Online Learning during the COVID-19 Pandemic}

The COVID-19 pandemic resulted in unprecedented school closures across the nation. By May 15, 2020, a majority of countries around the world had mandated the closing of all schools for the remainder of the school year. In the light of these sudden closures, educational institutions struggled to ensure continuity in education, with many of them accomplishing this by shifting to online learning.

Online learning has been associated with both positive and negative outcomes. For example, in a recent research, Fitzpatrick et al. (2020) reported that students who attended virtual charter schools (free public online schools were already in existence prior to the pandemic) demonstrated decreased achievement in both math and language arts with little improvement in performance over subsequent years. However, it is important to note that there are a number of differences between students at the virtual charter schools and students shifting to online learning due to the pandemic. For instance, on the positive side, student-to-teacher ratios in traditional schools are lower than in virtual charter schools, and students in traditional schools are likely to have already developed positive relationships with their teachers prior to the pandemic (Fitzpatrick et al. 2020). Other potential advantages of the switchover to online learning may be better retention of material by the students and a decrease in the time needed for them to learn ( $\mathrm{Li}$ and Lalani 2020). On the negative side, the lack of infrastructure available to public and private brick-and-mortar schools and limited time to effectively design and deliver online education prior to the school closures have challenged the transition to virtual delivery.

Teachers' and students' shift to online learning during the pandemic was sudden and without planning. This caused many difficulties in learning related to the use of 
technology in terms of curriculum design and internet skills. Many schools around the world started to prepare their teachers to overcome this stage by offering intensive workshops related to the use of technology in the classroom. On the other hand, from the side of the students, technology would lead to unequal opportunities for learning. This was due to whether students had successful access to technology and whether parental support during the lesson was present (Li and Lalani 2020).

\section{The Zoom Web Conference System}

The Zoom program allows for synchronous interactions between educators and students. In this online environment, individuals use a web-cam and a microphone to chat in real time, enabling interactions similar to those occurring in the traditional classroom setting (Rahayu 2020). Up to 200 individuals can actively participate in live sessions, and an additional 3000 attendees can passively view the session (Dharma et al. 2017). Although this program is subscription-based with education plans starting at $\$ 1800$ annually for 20 hosts, a free version is available which limits video sessions to $40 \mathrm{~min}$. Due to the COVID-19 pandemic, the company has removed this time limit on free basic accounts for elementary and secondary schools (Zoom Video Communications 2020).

Learners can participate in a variety of different educational activities within the Zoom environment. For example, communication-related activities include greeting others, classroom lectures, question and answers and group discussions in breakout rooms (Rahayu 2020). Activities related to materials comprise sharing slides or screens with students or educators, downloading homework assignments and uploading answers to questions (Rahayu 2020). Activities related to studying can take the form of answering polling questions, presenting lessons using slides or the whiteboard, classroom practice using the whiteboard or chat box and group work in breakout rooms (Rahayu 2020). Students and educators can also meet individually to discuss the student's work, and these sessions can be recorded for viewing later (McClendon et al. 2017).

The use of Zoom to teach in an online environment is associated with a number of advantages. In a study by Rahayu (2020), it is reported that over $60 \%$ of university students surveyed indicate that they were able to easily communicate through writing or speaking using this program. In addition, students were able to answer questions through the shared whiteboard, understand the lessons and collaborate effectively with peers (Ruhuya 2020; Dharma et al. 2017). Other advantages include effective interactions during tutoring sessions (Sayem et al. 2017), the ability of the educator to give control of the session over to a student, the availability of annotation tools such as lines and arrows and clear audio and a stable connection (Dharma et al. 2017; Ferns et al. 2020). Furthermore, as with other modes of synchronous online communication, Zoom can reduce feelings of social isolation and foster a sense of community among students (Lowenthal et al. 2020).

Despite these advantages, challenges to learning with Zoom exist. The features of Zoom may be difficult to access at first and may prove less intuitive in terms of their use (Dharma et al. 2017). In addition, as with other synchronous online programs, students may become distracted or engaged in multitasking and classes and lectures may stretch out longer than anticipated (Lowenthal et al. 2020; Ferns et al. 2020). Students using Zoom may also experience difficulties such as unreliable Internet connections, lack of a quiet environment, and inadequate speakers or microphones (Lowenthal et al. 2020; Ferns et al. 2020). 


\section{English as a Foreign Language (EFL) Teaching and Learning Online}

Amongst EFL students, satisfaction with online learning may depend in part upon personality traits. Shih et al. (2013) investigated the relationships between personality and online learning motivation and satisfaction amongst 153 EFL students in Turkey. Results indicated that students who demonstrated the personality traits of extraversion and conscientiousness reported higher satisfaction and motivation with online learning. Extraverted students were more active and open to new learning styles, while conscientious students were academically-oriented and willing to use new strategies to improve their performance. Additional factors related to improved motivation in the online environment included academic progress, desire to escape from the real world through the use of the social media, social contact, the desire to learn and the desire for self-development (Shih et al. 2013).

Regardless of personality traits, EFL students may hold positive views of online learning. The practice of blended learning as part of which students attend both face-to-face classes and online classes is associated with increased flexibility. In addition, students have also reported positive opinions regarding the use of online language learning platforms (Istifci 2017). An online learning environment may also help EFL students to improve oral language proficiency when they have the opportunity to record dialogue and participate in a flipped classroom whereby instruction is delivered online outside of class hours and class hours are used for practice (Wu et al. 2017). Collaborative online learning experiences have also been associated with improved writing performance and self-efficacy (Tai 2016). Furthermore, videoconferencing may improve the motivation of EFL students to speak in English amongst peers, although it may have little effect on perceived ability or confidence for using the language (Wu et al. 2011).

\section{Technology Acceptance Model}

Various theoretical models have been put forward to explore and explain factors that cause individuals to accept, reject or continue the use of new technology (Ajzen 1985; Ajzen and Fishbien 1980; Venkatesh and Davis 2000; Venkatesh et al. 2003). Drawing upon the Ajzen and Fishbien model of Theory of Reasoned Action (TRA), Davis (1989) introduced and developed the technology acceptance model (TAM) and provided a theoretical context that could explain the relationship of attitudes-intention-behavior. The TAM received empirical support for being robust and parsimonious in predicting technology acceptance and adoption. The TAM explains that individuals' performance of a specified behavior is determined by their behavioral intention to perform a certain task. There are two specific variables (perceived usefulness and perceived ease of use) which are hypothesized to be the fundamental determinants of user acceptance.

The TAM was created to predict the probability of an individual or organization adopting a new technology. This model was grounded in the theory of reasoned action, which explained that behavior was determined by the intention to perform that behavior, the attitude towards the behavior, and the social pressure to perform the behavior (Sheldon 2016). The TAM asserted that future use of technology could be predicted by applying the model at the time the technology was first used (Turner et al. 2010).

The TAM consists of five variables, including perceived ease of use, perceived usefulness, attitude toward use, behavioral intention to use, and actual use. The two most significant factors in the model are perceived ease of use, which refers to the belief that effort, 
will not be required and perceived usefulness, which describes the belief that the technology enhances job performance. These two variables, in conjunction with attitude toward use comprise the core variables of TAM. Outcomes variables include behavioral intention to use and actual use. Importantly, while behavioral intention is predictive of use, such a relationship may also exist in the opposite direction as positive user experience can determine behavioral intentions. Finally, external variables include subjective norm, computer self-efficacy, and facilitating conditions (Scherer et al. 2019). An explanation of these variables is provided in the table below.

\section{Perceived Usefulness}

Perceived usefulness is defined as the degree to which a person believes that using a particular technology will enhance his or her job performance (Davis 1989). People tend to use or not use an application based on the extent that they believe it will enhance their job performance. This means that attitude towards computer use, whether positive or negative is shaped by how users perceive the usefulness of technology in teaching and learning.

\section{Perceived Ease of Use}

Perceived ease of use is defined as the degree to which a person believes that using the system would be free of effort (Davis 1989). Furthermore, perceived usefulness has a direct impact on the intention to use while perceived ease of use influences intention to use indirectly through attitude. Sumak Hericko et al. (2011) highlight that the perceived ease of use is a factor that directly affects students' attitude. These variables are shown in Table 1 below:

In addition, Fig. 1 depicts a graphical representation of the TAM.

Table 1 TAM variables and definitions

\begin{tabular}{ll}
\hline Variable & Definition \\
\hline $\begin{array}{l}\text { External variables } \\
\text { Subjective norm }\end{array}$ & $\begin{array}{r}\text { The social pressure exerted by family and friends to engage in a particular } \\
\text { behavior (Agudo-Peregrina et al. 2014) }\end{array}$ \\
Computer self-efficacy & $\begin{array}{r}\text { The belief in one's ability to successfully complete a task using a computer } \\
\text { (Holden and Rada 2011) }\end{array}$ \\
Facilitating conditions & $\begin{array}{r}\text { The belief that adequate infrastructure exists to support the use of the technol- } \\
\text { ogy. Infrastructure may include knowledge, administration, organization, or } \\
\text { technical support (Nikou and Economides 2017) }\end{array}$
\end{tabular}

Core variables

Perceived ease of use

The belief that effort will not be required (Scherer et al. 2019)

Perceived usefulness

The belief that the technology enhances job performance (Scherer et al. 2019)

Attitude towards technology

A personal evaluation regarding the use of the technology (Lee and Lehto 2013)

Outcome variables

Behavioral intention

An individual's intention to use a piece of technology (Turner et al. 2010)

Actual use

An individual's use of technology (Scherer et al. 2019) 


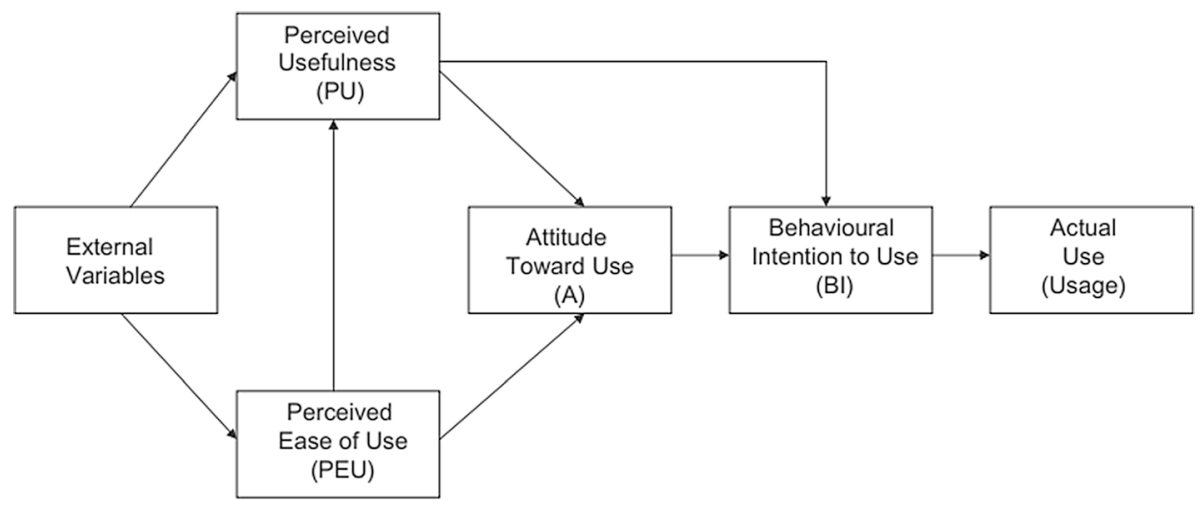

Fig. 1 The technology acceptance model (Turner et al. 2010)

\section{Gender and TAM}

The integration of TAM in language learning can be influenced by several factors. Researchers have paid considerable attention to studying the influence of gender on technology acceptance and use (e.g. Chou et al. 2011; González-Gómez et al. 2012; Schumacher and Morahan-Martin 2001; Terzis and Economides 2011; Thompson and Lim 1996; Whitley 1997). However, the results of these studies have revealed some contradictions.

Some studies have found that gender has an impact on the use of technology. For example, Thompson and Lim (1996) examined gender differences in the factors related to PC usage and found that females tended to view PCs as being less easy to use in comparison with their male peers. Analyzing changes in computer experiences amongst incoming college students by using data from two different samples, Schumacher and Morahan-Martin (2001) found that males were more experienced than females concerning computer programming and games. This led Schumacher and Morahan-Martin to conclude that the male students' greater experience with computing and gaming may contribute to their familiarity with computers and account for their competence and comfort with both the Internet and computers in comparison with female students.

Research has also found that girls feel less confident in dealing with computers than boys (Braak 2004). A study by González-Gómez et al. (2012) which inquired into gender differences with regard to e-learning sought to determine which aspects of teaching could be improved to boost the satisfaction of female and male students. In addition to observing significant differences between male and female students in terms of their satisfaction with e-learning in teaching, González-Gómez et al. (2012) found that female students assigned more importance to teaching methods, planning and to fostering active participation in the learning process than their male peers. A longitudinal study with 484 undergraduates found that gender differences were also reflected in attitude and intentions to use technology (Padilla-MeléNdez et al. 2013). According to the findings of this study, playfulness influenced the females' attitude toward using the system, whereas in males, the influence of playfulness on attitude was mediated by perceived usefulness.

On the other hand, some studies have found that there were no (or negligible) gender differences in the use of technology. For example, a study by Whitley (1997) found that gender differences in computer-related behaviors were small and did not differ as a function of study population. In addition, while identifying the constructs that affected male 
and female students' behavioral intention to use a computer based assessment, Terzis and Economides (2011) found that both genders were more likely to use the system if it were playful and its content was clear and relative to the course.

\section{Experience and TAM}

The acceptance of using technology can be influenced by the user's experience. It can be assumed that users with good experience may demonstrate a positive attitude toward technology and vice versa. A number of studies have been conducted to examine the impact of experience on TAM. Examining how TAM helped managers predict user intention to revisit a website and how this changed over time as users gained experience of the Internet and the website, Castañeda et al. (2007) found that the user's experience of the website played a moderating role. For less experienced users, perceived ease of use was found to be a more important factor in deciding to revisit the website, whereas perceived usefulness had more effect on more experienced users. In another study, Hsu and Lu (2004) applied TAM, which incorporated social influences and flow experience as belief-related constructs to predict users' acceptance of on-line games. The proposed model was empirically evaluated using survey data collected from 233 users about their perceptions of online games. The results revealed that social norms, attitude, and flow experience explained about $80 \%$ of the game playing.

\section{Research Hypotheses}

The primary research question for this study is as below:

What are student perceptions of Technology, PU, Activities, PEU, Attitude and Behavioral Intention for using Zoom in language learning?

This question is examined in terms of six specific hypotheses that are directly based upon TAM:

Hypothesis 1. Computer Self-Efficacy will positively and significantly influence the overall technology acceptance.

Hypothesis 2: Perceived usefulness use will positively and significantly influence students' attitude towards computer use.

Hypothesis 3: Perceived ease of use will significantly and positively influence students' perceived usefulness.

Hypothesis 4: Perceived ease of use will significantly and positively influence students' attitude towards computer use.

Hypothesis 5: Gender of the students will significantly and positively influence students' acceptance of using Zoom in language learning.

Hypothesis 6: The experience of the students will significantly and positively influence students' acceptance of using Zoom in language learning.

\section{Methods}

Extended TAM was used for exploring the use of Zoom in language learning. Based on extensive literature review and findings of an exploratory study, a conceptual framework was developed using computer self-Efficacy, perceived usefulness, actual use of Zoom, 
perceived ease of use, Attitude, Behavioral Intention of English through using Zoom to explore the implementation of Zoom in language learning.

\section{Participants}

The research participants comprised university undergraduate students enrolled in Departments of English in selected Saudi universities. The students used Zoom as a tool for learning along with BlackBoard in the academic year 2019/2020, the period of learning affected by COVID-19 university closures. Participation in the survey was based on the willingness of the students who used Zoom in this semester to take part in the study. Seventy-five participants responded to an online questionnaire about their perception of using Zoom in language learning.

The sample comprised $46.6 \%$ male and $57.14 \%$ female students. Regarding experience with technology, $21.3 \%$ of the participants reported that they had excellent skills in using Zoom and $46.7 \%$ of them reported that they had very good skills in using Zoom. Also, $25.3 \%$ of the participants reported that they had good skills in using Zoom. Only, $6.7 \%$ of the participants reported that they had fair skills in using Zoom (Table 2).

\section{Instrument}

The instrument used in this study was a modification of a questionnaire developed by Yang and Wang (2019). The questionnaire had two main sections subsuming questions related to demographic profiles and questions related to the items of the constructs in the research model. Demographic Information pertained to the information about the participants' age, gender and experience in using Zoom. In the second part of the questionnaire, respondents indicated their agreement level on every item by recording their response in accordance with a 5-point Likert scale. These items were taken from several relevant studies with confirmed reliability and validity of the instruments used that had been used. In the Likert scale used, 1 represented "strongly disagree", 2 represented "disagree", 3 represented "neutral", 4 represented "agree", and 5 represented "strongly agree." Items of the constructs and the sources they have been included in are appended in "Appendix". The questionnaire was based on six constructs: Computer Self-Efficacy (3 items), Perceived Usefulness (7 items), Actual Use of Zoom (3 items), Perceived Ease of Use (4 items), Attitude (4 items), and Behavioral Intention of Using Zoom (5 items). The reliability of the questionnaire was

Table 2 Demographic background of study participants

\begin{tabular}{lcc}
\hline & $\mathrm{N}$ & Percent \\
\hline Gender & 35 & \\
Male & 40 & 46.6 \\
Female & & 57.14 \\
Experience & 5 & 6.7 \\
Fair & 19 & 25.3 \\
Good & 35 & 46.7 \\
Very good & 16 & 21.3 \\
Excellent & & \\
\hline
\end{tabular}


Table 3 The questionnaire reliability

\begin{tabular}{ll}
\hline Cronbach's alpha & No. of items \\
\hline .933 & 26 \\
\hline
\end{tabular}

verified with Cronbach's alpha $(\alpha)$ using SPSS. The reliability of the questionnaire was .93 as shown in Table 3.

\section{Data Collection and Procedures}

Data were collated from the questionnaire responses of 75 Saudi students. A two-step approach recommended by Anderson and Gerbing (1988) was used to analyze the model in this study. First, the measurement model was assessed to evaluate the reliability and validity of the variables, and then the structural model was performed to test the significance of the relationships between the variables. The descriptive statistics and Cronbach's alpha coefficients were obtained through SPSS 22.0. In addition, this software was used to evaluate the relationships in the structural model.

\section{Data Analysis}

The Statistical Package for the Social Sciences (SPSS) version 22.0 was used to analyze the data. A Pearson's correlation coefficients (r) between Computer Self-Efficacy, PU, activities, PEU, attitude, and Behavioral Intention was used. According to Taylor (1990), a Pearson's correlation coefficient between .68 and 1.0 was considered high. In order to identify the strengths of the relationships between the six constructs, a correlation coefficient analysis was performed. A correlation coefficient analysis describes the strength and direction of the linear relationship between two variables and the degree of correlation indicates the strength of an association between them (Pallant 2011). The plus and minus signs indicate whether there is a positive correlation: as the independent variable increases, the dependent variable also increases; or a negative correlation: as the independent variable increases, the dependent variable decreases (Pallant 2011). A perfect correlation coefficient value of 1 or -1 between two variables indicates that a value of one variable can be determined precisely by knowing the value of the other variable. Correlation coefficient values can be used to determine the effects of an independent variable on a dependent variable. This guideline was used to understand the strength of the relationships between the six constructs.

\section{Results and Discussion}

The descriptive data of the questionnaire items including correlations between the constructs are presented in Table 4.

Table 4 shows the results of testing the discriminant validity of the measure scales. According to Teo and Noyes (2011), discriminant validity will be present when the variance shared between a construct and any other construct in the model was less than the 
Table 4 The correlation between the constructs

\begin{tabular}{lllllll}
\hline Construct & $\begin{array}{l}\text { Computer } \\
\text { self-efficacy }\end{array}$ & PU & Actual use & PEU & Attitude & $\begin{array}{l}\text { Behavio- } \\
\text { ral inten- } \\
\text { tion }\end{array}$ \\
\hline Computer self-efficacy & 1 & $.519^{* *}$ & $.286^{*}$ & $.341^{* *}$ & $.421^{* *}$ & $.494^{* *}$ \\
& & .000 & .013 & .003 & .000 & .000 \\
PU & 75 & 75 & 75 & 75 & 75 & 75 \\
& $.519 * *$ & 1 & $.444^{* *}$ & $.677^{* *}$ & $.829 * *$ & $.812^{* *}$ \\
Actual use & .000 & & .000 & .000 & .000 & .000 \\
PEU & 75 & 75 & 75 & 75 & 75 & 75 \\
& $.286^{*}$ & $.444^{* *}$ & 1 & $.539 * *$ & $.459 * *$ & $.606^{* *}$ \\
Attitude & .013 & .000 & & .000 & .000 & .000 \\
& 75 & 75 & 75 & 75 & 75 & 75 \\
Behavioral intention & .003 & $.677^{* *}$ & $.539 * *$ & 1 & $.835 * *$ & $.757 * *$ \\
& 75 & .000 & .000 & & .000 & .000 \\
\hline
\end{tabular}

$* *$ Correlation is significant at the .01 level (2-tailed)

*Correlation is significant at the .05 level (2-tailed)

variance of the constructs shared with its indicators. If the square roots of the average variance extracted (AVE) was greater than the off-diagonal elements in the corresponding rows and columns, it would suggest that the given construct was more strongly correlated with its indicators than with the other constructs in the model. The elements in the matrix diagonals of this proposed model, representing the square roots of the AVEs, was greater in all cases than the off-diagonal elements in their corresponding rows and columns. The values suggested that discriminant validity was present at the latent variables in the proposed research model. In this study, the AVEs with strong correlations were written in bold as shown in Table 4. They indicate strong correlations between the constructs. For example, the AVE between attitude and PU is .829, which indicates strong correlation between these two constructs. In addition, the AVE correlation between behaviour intention and PU is strong (.812). Similarly, the AVE correlation between behaviour intention and attitude is strong (.835). Based on the results shown in Table 4, each hypothesis is examined as follows:

Hypothesis 1 Computer Self-Efficacy will positively and significantly influence the overall technology acceptance.

Based on the results shown in Table 4, it is clear that there is a substantial positive relationship between Computer Self-Efficacy and PU of Zoom (.51). The results also revealed that there is a positive relationship between Computer Self-Efficacy and actual Zoom (.28). In addition, there is a considerable positive relationship between Computer Self-Efficacy and PEU (.34). The results also show that there is a considerable positive relationship between Computer Self-Efficacy and Attitude (.42) and between Computer Self-Efficacy and Behavioral Intention (.49). Overall, the relationships found between Computer Self-Efficacy and the other variable is positive. Thus, the first research question is fully supported. It suggests that in the educational setting there is a relationship 
between Computer Self-Efficacy and the use of Zoom. The findings in this study are in line with other studies, which suggest that a successful relationship exists between CSF and TAM (Ariff 2012; Reid and Levy 2008).

Hypothesis 2 Perceived usefulness will positively and significantly influence students' attitude towards computer use.

Based on the results shown in Table 4, it is clear that there is a substantial positive relationship between PU and Computer Self-Efficacy of Zoom (.51). The results also reveal that there is a positive relationship between PU and actual use (.44). In addition, there is a considerable positive relationship between PU and PEU (.67). The results also show that there is a strong positive relationship between PU and Attitude (.82) and between PU and Behavioral Intention (.81). Overall, the relationships found between PU and the other variable are positive. Thus, the second research question is fully supported. It suggests that in the educational setting there is a relationship between PU and use of Zoom. The findings in this study are in line with the current research suggesting the existence of a positive and strong relationship among perceived usefulness and attitude towards computer use to behavioral intention (Lin 2011; Moran et al. 2011; Pynoo et al. 2011; Sumak et al. 2011; Teo 2009).

Hypothesis 3 Perceived ease of use will significantly and positively influence students' perceived usefulness.

The results shown in Table 4 indicate that there is a substantial positive relationship between PEU and Computer Self-Efficacy of using Zoom (.28). The results also reveal that there is a positive relationship between PEU and PU (.44). Moreover, there is a considerable positive relationship between PEU and attitude (.45). The results also show that there is a substantial positive relationship between PEU and Behavioral Intention (.60). Overall, the relationships found between PEU and the other variable is positive and support the third research question. The findings are also in agreement with previous studies involving TAM (Liu et al. 2010; Tarhini et al. 2014; Weng and Tsai 2015).

Hypothesis 4 Perceived ease of use will significantly and positively influence students' attitude towards computer use.

The results shown in Table 4 indicate that there is a substantial positive relationship between attitude and Computer Self-Efficacy in using Zoom (.34). The results also reveal that there is a positive relationship between attitude and PU (.67). Further, there is a considerable positive relationship between attitude and activities (.53). The results also show that there is a substantial positive relationship between attitude and Behavioral Intention (.75). Overall, the relationships found between attitude and other variable are positive and support the fourth research question. The findings in this study are in line with other studies like (Chen 2010; Compeau and Higgins 1995; Park 2009; Venkatesh 2000; Wong et al. 2010).

Hypothesis 5 Gender of the students will significantly and positively influence students' acceptance of using Zoom in language learning. 
Table 5 The correlation between gender and the other variable

\begin{tabular}{lllllll}
\hline Variable & $\begin{array}{l}\text { Computer self- } \\
\text { efficacy }\end{array}$ & PU & Actual use & PEU & Attitude & $\begin{array}{l}\text { Behavio- } \\
\text { ral inten- } \\
\text { tion }\end{array}$ \\
\hline Gender & $-.348^{* *}$ & $-301^{* *}$ & -.175 & -.127 & $-.262^{*}$ & -.167 \\
& .002 & .009 & .134 & .278 & .023 & .151 \\
& 75 & 75 & 75 & 75 & 75 & 75 \\
\hline
\end{tabular}

**Correlation is significant at the .01 level (2-tailed)

*Correlation is significant at the .05 level (2-tailed)

The results in Table 5 show a negative correlation between the students' gender and their acceptance of using Zoom for language learning. This indicates that gender had no impact on TAM. The finding of this study is in line with studies carried out by Whitley (1997); and Terzis and Economides (2011) who found that both genders were more likely to use the technology well. In some studies, the results reveal that there are differences between male and female students regarding their perceptions and effects on the relationships among the constructs that affect the behavioral intention to use computers and e-learning (e.g. Venkatesh 2000). However, the literature did not provide definite results. Concerning perceptions and attitudes, previous studies showed that male students were more positive towards computer use in a learning context (e.g. Enoch and Soker 2006; Koohang 2004). Moreover, Tondeur et al. (2008) found that male teachers used computers more often for teaching purposes than females. However, some studies found that there was no significant difference between males and females in their perceptions towards e-learning use (e.g. Hung et al. 2010).

Hypothesis 6 The experience of the students will significantly and positively influence students' acceptance of using Zoom in language learning.

The results in Table 6 show a slightly positive correlation between the students' experience and their acceptance of using Zoom in language learning. Experience has proved to be a significant predictor of perceived usefulness, which suggests that increasing experience may lead to more perceptions of usefulness. This result is also in line with the prior research (Castañeda et al. 2007; Hsu and Lu 2004) which showed that users with good experience had a positive attitude toward technology.

Table 6 The correlation between students' experience and the other variable

\begin{tabular}{lllllll}
\hline Variable & $\begin{array}{l}\text { Computer self- } \\
\text { efficacy }\end{array}$ & PU & Actual use & PEU & Attitude & $\begin{array}{l}\text { Behavio- } \\
\text { ral inten- } \\
\text { tion }\end{array}$ \\
\hline Experience & .100 & $.259^{*}$ & .101 & $.346^{* *}$ & $.332^{* *}$ & $.310^{* *}$ \\
& .393 & .025 & .389 & .002 & .004 & .007 \\
& 75 & 75 & 75 & 75 & 75 & 75 \\
\hline
\end{tabular}

\footnotetext{
**Correlation is significant at the .01 level (2-tailed)

*Correlation is significant at the .05 level (2-tailed)
} 
The study results are in line with the study of Hsu and Lu (2004) who found that social issues and experience predict users' acceptance of on-line games. The results revealed that social norms, attitude, and flow experience explained about $80 \%$ of the game playing.

\section{Conclusion}

This study applied the extended model of TAM on the use of the Zoom application for language learning. It also examined the impact of gender and experience on the use of technology. The study concluded that there is a strong positive correlation between the actual use of Zoom and the students' attitudes and behavioral intention. In addition, there was a positive correlation between computer self-efficacy and the other variables (i.e. PU, actual use, PEU, attitude and behavioral intention). The results also revealed that there was no correlation between gender and any variable of the model. However, experience has a positive correlation with the variables of TAM.

This study has some limitations that may be addressed in future studies. Firstly, the sample size of this study is somewhat small, which might limit the generalizability of the results. A larger sample size in future studies may generate findings that can contribute to the power of the model. Secondly, the participants of this study belong to the same cultural and linguistic background. To further validate the findings, students with different cultural backgrounds may be included in the sample. Therefore, it is better to involve students of different language levels (i.e. beginner, intermediate and advanced) in future research. Thirdly, the findings of this study are based on the analysis of selfreported data. Future studies may include observational data for the purpose of triangulating the findings and overcoming the shortcomings of self-reported data. Fourthly, the cultural issues may affect the perception of using Zoom and any other e-learning platforms. So, it is recommended in future studies to take account of cultural issues in their investigations. Lastly, this study is a cross-sectional investigation of students' perception of using Zoom. As such, perceptions might evolve over time, in the future; a longitudinal study including a variety of data sources (e.g. observations and interviews) may capture the intention to use Zoom more comprehensively.

\section{Pedagogical Implications}

The result of the study concluded that TAM had an effect on university students' intention to use Zoom as a tool for learning. For that reason, there is a potential for practical application in the development and management of Zoom in the university. Educators and managers should make an effort to improve university students' skills in using Zoom and any other platforms for e-learning. It is necessary that managers and developers of e-learning in the university level help students increase their perception positively by using e-learning in their courses. 
Acknowledgements Researchers supporting project number (RSP-2020/521), King Saud University, Riyadh, Saudi Arabia.

\section{Compliance with Ethical Standards}

Conflict of interest The authors declare that they have no conflict of interest.

Consent to Participate Informed consent was obtained from all individual participants included in the study. Ref No: KSU-HE-20-324, Deanship of Scientific Research, King Saud University (Attached a document approved the college).

\section{Appendix: The Questionnaire}

Gender:
Age:
Experience in using zoom: (Excellent-Very Good-Good-Fair-Poor)
Computer Self-Efficacy

1. Zoom provides assistance when there is a language problem.

2. E-mail inquiries can be made when there is a problem.

3. Zoom offers good Computer Self-Efficacy.

Perceived usefulness

4. Zoom helps me to learn more efficiently.

5. Zoom improves my academic performance.

6. Using Zoom to learn English is helpful.

7. The audio sound and the camera in zoom add to the authenticity of learning.

8. Zoom makes English easier to learn at the university.

9. Zoom gives me more control over my learning.

10. Zoom is advantageous for learning English.

Actual use of Zoom

11. I believe that Zoom helps me cooperate with classmates.

12. I believe that assignments help me improve my English performance.

13. I believe that a discussion forum helps me improve my English performance.

Perceived ease of use

14. Learning to use Zoom is easy for me.

15. Log in and out of Zoom is fast and clear.

16. It is easy to get materials from Zoom.

17. Overall, I believe that Zoom is easy to use. 
Attitude

18. Learning on Zoom is fun.

19. Using Zoom for learning is a good idea.

20. Zoom is an attractive way to learn.

21. I like using zoom for learning.

\section{Behavioral Intention of English through using Zoom}

22. I believe Zoom is useful for me as a student.

23. Zoom helps me improve my English skills.

24. I feel comfortable using Zoom to improve my English.

25. Zoom materials are useful to me for learning English.

26. I think Zoom should be used in English classes in the future.

\section{References}

Agudo-Peregrina, Á. F., Hernández-García, Á., \& Pascual-Miguel, F. J. (2014). Behavioral intention, use behavior and the acceptance of electronic learning systems: Differences between higher education and lifelong learning. Computers in Human Behavior, 34, 301-314. https://doi.org/10.1016/j. chb.2013.10.035.

Ajzen, I. (1985). From intentions to actions: A theory of planned behavior. In J. Kuhl \& J. Beckmann (Eds.), Action control: From cognition to behavior (pp. 11-39). New York: Springer.

Ajzen, I., \& Fishbein, M. (1980). Understanding attitudes and predicting social behavior. New Jersey: Pretice-Hall.

Al Fadda, H. A. (2020). Determining how social media affects learning English: An investigation of mobile applications instagram and snap chat in TESOL classroom. Arab World English Journal, 11(1), 3-11. https://doi.org/10.2139/ssrn.3581296.

Anderson, J. C., \& Gerbing, D. W. (1988). Structural equation modeling in practice: A review and recommended two-step approach. Psychological Bulletin, 103(3), 411. https://doi. org/10.1037/0033-2909.103.3.411.

Ariff, M. S. (2012). The effect of computer self-efficacy and technology acceptance model on behavioral intention in internet banking system. Social and Behavioral Sciences, 57(2012), 448-452. https://doi. org/10.1016/j.sbspro.2012.09.1210.

Braak, J. (2004). Domains and determinants of university students' self-perceived computer competence. Computers \& Education, 43(3), 299-312. https://doi.org/10.1016/j.compedu.2003.09.006.

Castañeda, J. A., Muñoz-Leiva, F., \& Luque, T. (2007). Web acceptance model (WAM): Moderating effects of user experience. Information \& Management, 44(4), 384-396. https://doi.org/10.1016/j. im.2007.02.003.

Chen, R. (2010). Investigating models for pre-service teachers' use of technology to support student-centered learning. Computer \& Education, 55, 32-42. https://doi.org/10.1016/j.compedu.2009.11.015.

Chou, Ch., Wu, H Ch., \& Chen, Ch H. (2011). Re-visiting college students' attitudes toward the Internetbased on a 6-T model: Gender and grade level difference. Computers \& Education, 56(4), 939-947. https://doi.org/10.1016/j.compedu.2010.11.004.

Compeau, D. R., \& Higgins, C. A. (1995). Computer self-efficacy: Development of a measure and initial test. MIS Quarterly, 19(2), 189-211. https://doi.org/10.2307/249688.

Davis, F. D. (1989). Perceived usefulness: Perceived ease of use and user acceptance of information technology. Management Information Systems Quarterly., 13(3), 983-1003.

Dharma, H. R. C., Asmarani, D., \& Dewi, U. P. (2017). Basic Japanese grammar and conversation e-learning through Skype and Zoom online application. Procedia Computer Science, 116, 267-273. https:// doi.org/10.1016/j.procs.2017.10.055. 
Enoch, Y., \& Soker, Z. (2006). Age, gender, ethnicity and the digital divide: University students' use of web-based instruction. Open Learning, 21(2), 99-110.

Ferns, S., Cappon, A., Duff, A., Marshall, A., Ryan, B., Thompson, B.,... \& Gray, G. (2020). Technology tools for teaching in higher education, the practical handbook series.

Fitzpatrick, B., Berends, M., Ferrare, J. J., \& Waddington, R. J. (2020, June 2). Virtual charter schools and online learning during COVID-19. The Brookings Institute. Retrieved from https://www.brook ings.edu/blog/brown-center-chalkboard/2020/06/02/virtual-charter-schools-and-online-learning-durin g-covid-19/.

González-Gómez, F., Guardiola, J., Martín-Rodríguez, O., \& Montero-Alonso, M. A. (2012). Gender differences in e-learning satisfaction. Computers \& Education, 58(1), 283-290. https://doi.org/10.1016/j. compedu.2011.08.017.

Holden, H., \& Rada, R. (2011). Understanding the influence of perceived usability and technology selfefficacy on teachers' technology acceptance. Journal of Research on Technology in Education, 43(4), 343-367. https://doi.org/10.1080/15391523.2011.10782576.

Hsu, C. L., \& Lu, H. P. (2004). Why do people play on-line games? An extended TAM with social influences and flow experience. Information \& Management, 41(7), 853-868. https://doi.org/10.1016/j. im.2003.08.014.

Hung, M.-L., Chou, C., Chen, C.-H., \& Own, Z.-Y. (2010). Learner readiness for online learning: Scale development and student perceptions. Computers \& Education, 55(4), 1080-1090.

Istifci, I. (2017). Perceptions of Turkish EFL students on online language learning platforms and blended language learning. Journal of Education and Learning, 6(1), 113-121. https://doi.org/10.5539/jel. v6n1p113.

Koohang, A. (2004). Students' perceptions toward the use of the digital library in weekly web-based distance learning assignments portion of a hybrid program. British Journal of Educational Technology, 35(5), 617-626.

Landry, B. J., Griffeth, R., \& Hartman, S. (2006). Measuring student perceptions of blackboard using the technology acceptance model. Decision Sciences Journal of Innovative Education, 4(1), 87-99. https:// doi.org/10.1111/j.1540-4609.2006.00103.x.

Lee, D. Y., \& Lehto, M. R. (2013). User acceptance of YouTube for procedural learning: An extension of the technology acceptance model. Computers \& Education, 61, 193-208. https://doi.org/10.1016/j. compedu.2012.10.001.

Li, C., \& Lalani, F. (2020, April 29). The COVID-19 pandemic has changed education forever. This is how. World Economic Forum. Retrieved from https://www.weforum.org/agenda/2020/04/coronavirus-educa tion-global-covid19-online-digital-learning/.

Lin, K. (2011). E-Learning continuance intention: Moderating effects of user E-learning experience. Computer \& Education, 56(2), 515-526. https://doi.org/10.1016/j.compedu.2010.09.017.

Liu, X. (2010). Empirical testing of a theoretical extension of the technology acceptance model: An exploratory study of educational wikis. Communication Education, 59(1), 52-69. https://doi. org/10.1080/03634520903431745.

Liu, I. F., Chen, M. C., Sun, Y. S., Wible, D., \& Kuo, C. H. (2010). Extending the TAM model to explore the factors that affect intention to use an online learning community. Computers \& Education, 54(2), 600-610. https://doi.org/10.1016/j.compedu.2009.09.009.

Lowenthal, P., Borup, J., West, R., \& Archambault, L. (2020). Thinking beyond Zoom: Using asynchronous video to maintain connection and engagement during the COVID-19 pandemic. Journal of Technology and Teacher Education, 28(2), 383-391.

McClendon, C., Neugebauer, R. M., \& King, A. (2017). Grit, growth mindset, and deliberate practice in online learning. Journal of Instructional Research, 8, 8-17. https://doi.org/10.9743/JIR.2017.

Moore, J. L., Dickson-Deane, C., \& Galyen, K. (2011). e-Learning, online learning, and distance learning environments: Are they the same? The Internet and Higher Education, 14(2), 129-135.

Moran, M., Hawkes, M., \& Gayar, O. E. (2011). Tablet personal computer integration in higher education: Applying the unified theory of acceptance and technology model to understands supporting factors. Journals of Education Computing Research., 42(1), 79-101. https://doi.org/10.2190/EC.42.1.d.

Nikou, S. A., \& Economides, A. A. (2017). Mobile-based assessment: Investigating the factors that influence behavioral intention to use. Computers \& Education, 109, 56-73. https://doi.org/10.1016/j.compe du.2017.02.005.

Padilla-MeléNdez, A., Del Aguila-Obra, A. R., \& Garrido-Moreno, A. (2013). Perceived playfulness, gender differences and technology acceptance model in a blended learning scenario. Computers \& Education, 63, 306-317. https://doi.org/10.1016/j.compedu.2012.12.014.

Pallant, J. (2011). Survival manual. In A step-by-step guide to data analysis using SPSS. 
Park, S. Y. (2009). An analysis of the technology acceptance model in understanding university students' behavioral intention to use e-learning. Educational Technology \& Society, 12(3), 150-162. https://doi. org/10.1109/IIAI-AAI.2014.14.

Pynoo, B., Devolder, P., Tondeur, J., Braak, J., Duyck, W., \& Dyck, P. (2011). Predicting secondary school teachers' acceptance and use of a digital learning environment: A cross-sectional study. Computers in Human Behavior, 27(2), 568-575. https://doi.org/10.1016/j.chb.2010.10.005.

Rahayu, D. (2020). Students' e-learning experience through a synchronous Zoom web conference system. Journal of ELT Research: The Academic Journal of Studies in English Language Teaching and Learning, 5(1), 68-79.

Reid, M., \& Levy, R. (2008). Integrating trust and computer self-efficacy with TAM: An empirical assessment of costumer acceptance of banking information system (BIS) in Jamaica. Journal of Internet Banking and Commerce., 12(3), 1-18.

Sayem, A. S. M., Taylor, B., McClanachan, M., \& Mumtahina, U. (2017). Effective use of zoom technology and instructional videos to improve engagement and success of distance students in engineering. In 28th annual conference of the Australasian association for engineering education (AAEE 2017) (p. 926). Australasian Association for Engineering Education.

Scherer, R., Siddiq, F., \& Tondeur, J. (2019). The technology acceptance model (TAM): A meta-analytic structural equation modeling approach to explaining teachers' adoption of digital technology in education. Computers \& Education, 128, 13-35. https://doi.org/10.1016/j.compedu.2018.09.009.

Schumacher, P., \& Morahan-Martin, J. (2001). Gender, internet and computer attitudes and experiences. Computers in Human Behavior, 17(1), 95-110. https://doi.org/10.1016/S0747-5632(00)00032-7.

Sheldon, P. (2016). Facebook friend request: Applying the theory of reasoned action to student-teacher relationships on Facebook. Journal of Broadcasting \& Electronic Media, 60(2), 269-285. https://doi. org/10.1080/08838151.2016.1164167.

Shih, H. F., Chen, S. H. E., Chen, S. C., \& Wey, S. C. (2013). The relationship among tertiary level EFL students' personality, online learning motivation and online learning satisfaction. Procedia-Social and Behavioral Sciences, 103, 1152-1160. https://doi.org/10.1016/j.sbspro.2013.10.442.

Sumak, B., Hericko, M., Pusnik, M., \& Polancic, (2011). Factors affecting acceptance and use of Moodle: An empirical study based on TAM. Slovenian Society Informatika, 35(1), 91-100. https://doi. org/10.4018/IJICTE.2017010102.

Tai, H. C. (2016). Effects of collaborative online learning on EFL learners' writing performance and selfefficacy. English Language Teaching, 9(5), 119-133. https://doi.org/10.5539/elt.v9n5p119.

Tarhini, A., Hone, K., \& Liu, X. (2014). Measuring the moderating effect of gender and age on e-learning acceptance in England: A structural equation modeling approach for an extended technology acceptance model. Educational Computing Research, 51(2), 163-184. https://doi.org/10.2190/ec.51.2.b.

Taylor, R. (1990). Interpretation of the correlation coefficient: A basic review. Journal of diagnostic medical sonography, 6(1), 35-39. https://doi.org/10.1177/875647939000600106.

Teo, T. (2009). The impact of subjective norm and facilitating conditions on pre-service teachers' attitude toward computer use: a structural equation modelling of an extended technology acceptance model. Journal Education Computing Research, 40(1), 89-109. https://doi.org/10.2190/EC.40.1.d.

Teo, T., \& Noyes, J. (2011). An assessment of the influence of perceived enjoyment and attitude on the intention to use technology among pre-service teachers: A structural equation modelling approach. Computer \& Technology, 57(2), 1645-1653.

Terzis, V., \& Economides, A. A. (2011). Computer based assessment: gender differences in perceptions and acceptance. Computers in Human Behavior, 27(6), 2108-2122. https://doi.org/10.1016/j. chb.2011.06.005.

Thompson, S. H. T., \& Lim, V. K. G. (1996). Factors influencing personal computer usage: The gender gap. Women in Management Review, 11(8), 18-26. https://doi.org/10.1108/09649429610148746.

Tondeur, J., Valcke, M., \& van Braak, J. (2008). A multidimensional approach to determinants of computer use in primary education: Teacher and school characteristics. Journal of Computer Assisted learning, 24(6), 494-506.

Turner, M., Kitchenham, B., Brereton, P., Charters, S., \& Budgen, D. (2010). Does the technology acceptance model predict actual use? A systematic literature review. Information and Software Technology, 52(5), 463-479. https://doi.org/10.1016/j.infsof.2009.11.005.

Venkatesh, V. (2000). Determinants of perceived ease of use integrating control, intrinsic motivation, and emotion into the technology acceptance model. Information Systems Research, 1194, 342-365. https:// doi.org/10.1287/mnsc.46.2.186.11926.

Venkatesh, V., \& Davis, F. D. (2000). A theoretical extension of technology acceptance model: Four longitudinal field studies. Management Science, 46, 186-204. https://doi.org/10.1287/mnsc.46.2.186.11926. 
Venkatesh, V., Morris, M. G., Davis, G. B., \& Davis, F. B. (2003). User acceptance of information technology: Toward a Unified view. MIS Quarterly, 27(3), 425-478. https://doi.org/10.5555/2017197.20172 02 .

Weng, C., \& Tsai, C. (2015). Social support as a neglected e-learning motivator affecting trainee's decisions of continuous intentions of usage. Australasian Journal of Educational Technology, 31(2), 177-192. https://doi.org/10.14742/ajet.1311.

Whitley, B. E. (1997). Gender differences in computer-related attitudes and behavior: A meta-analysis. Computers in Human Behavior, 13(1), 1-22. https://doi.org/10.1016/S0747-5632(96)00026-X.

Winthrop, R. (2020, March 31). COVID-19 and school closures: What can countries learn from past emergencies? Brookings Institute. Retrieved from https://www.brookings.edu/research/covid-19-and-schoo 1-closures-what-can-countries-learn-from-past-emergencies/.

Wong, K. T., Goh, S. C., Fahri, Hafizul, \& Osman, Rosma. (2010). Computer attitudes and use among novice teachers; The moderating effects of school environment. Malaysian Journal of Learning and Instruction, 7, 93-112.

World Health Organization. (2020). WHO timeline-COVID-19. Retrieved from https://www.who.int/ news-room/detail/27-04-2020-who-timeline-covid-19?gclid=EAIaIQobChMIif-81rCh6gIVgY3ICh 1x3gZPEAAYASAAEgJ24vD_BwE.

Wu, W. C. V., Hsieh, J. S. C., \& Yang, J. C. (2017). Creating an online learning community in a flipped classroom to enhance EFL learners' oral proficiency. Journal of Educational Technology \& Society, 20(2), 142-157.

Wu, W. C. V., Yen, L. L., \& Marek, M. (2011). Using online EFL interaction to increase confidence, motivation, and ability. Journal of Educational Technology \& Society, 14(3), 118-129.

Yang, Y., \& Wang, X. (2019). Modeling the intention to use machine translation for student translators: An extension of Technology Acceptance Model. Computers \& Education, 133, 116-126. https://doi. org/10.1016/j.compedu.2019.01.015.

Zoom Video Communications. (2020). Zoom for education. Retrieved from https://zoom.us/education.

Publisher's Note Springer Nature remains neutral with regard to jurisdictional claims in published maps and institutional affiliations. 